\title{
Paget's Disease of the Skull: A "Cotton Wool" Appearance Choy $\mathrm{KH}^{*}$ \\ Department of Medicine, Barwon Health, Geelong, Victoria, Australia
}

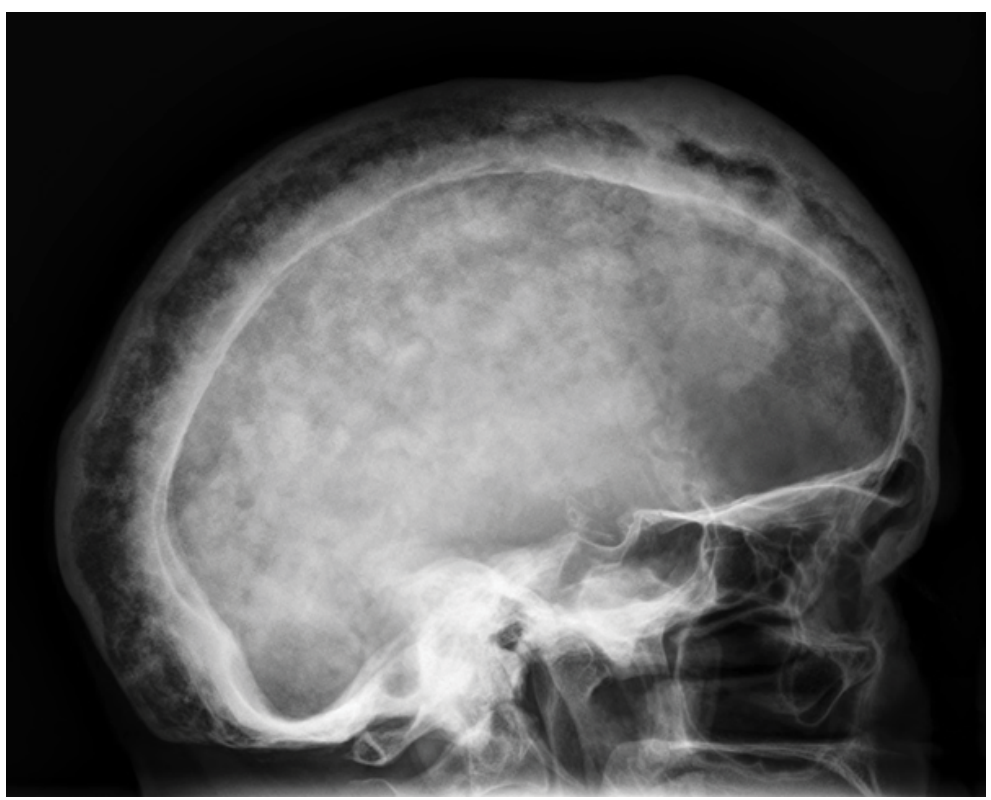

Figure 1: X-ray of the skull showed bony expansion with cortical thickening and a "cotton wool" appearance due to areas of sclerosis.

\section{Case Presentation}

An 80-year-old woman presented with headaches and increasing head size. X-ray of the skull demonstrated considerable bony expansion with cortical thickening and a "cotton wool" appearance due to areas of osteosclerosis (Figure 1). These features are characteristic of Paget's disease of the skull [1]. Serum alkaline phosphatase (ALP) was elevated at 1744 U/L (reference range, 20-175 U/L) and whole-body bone scan showed active monostotic Paget's disease of the skull. She was started on alendronate. At 6 months' follow-up, normalization of serum ALP was achieved and her headaches improved. She had regular follow-up with repeat measurements of serum ALP to monitor for relapse of her condition.

First described by Sir James Paget in 1877, Paget's disease of bone (PDB) is a chronic bone disorder characterized by excessive and disorganized bone remodeling [1]. It may involve a single bone (monostotic) or multiple bones (polyostotic). PDB predominantly affects the elderly and is the second most common metabolic bone disease after osteoporosis. The prevalence of PDB is the highest in the United Kingdom and Western Europe, and is common in populations of British descent [1,2]. The etiology of PDB is unclear, but genetic and environmental factors have been associated with the development of this disorder $[2,3]$. Imaging is essential in establishing the diagnosis and to assess the extent of the disease [2]. Patients with symptomatic disease should be treated and bisphosphonates are the treatment of choice. Serum ALP, the most commonly used marker of disease activity in PDB, should be measured periodically once remission of PDB has been achieved to monitor for relapse of the disorder $[2,3]$.

\section{References}

1. Theodorou DJ, Theodorou SJ, Kakitsubata Y (2011) Imaging of Paget disease of bone and its musculoskeletal complications: Review. AJR Am J Roentgenol 196: S64-75.

2. Shaker JL (2009) Paget's Disease of Bone: A Review of Epidemiology, Pathophysiology and Management. Therapeutic Advances in Musculoskeletal Disease 1: 107-125.

3. Siris ES (1998) Paget's Disease of Bone. J Bone Miner Res 13: 1061-1065.

*Corresponding author: Kay Hau Choy, Department of Medicine, Barwon Health, Geelong 3220, Victoria, Australia, Tel: +61 3 4215 000; E-mail: kayhau_choy@yahoo.com

Citation: Choy KH (2017) Paget's Disease of the Skull: A “Cotton Wool” Appearance. Int J Clin Med Imaging 4: 567. doi:10.4172/2376-0249.1000567

Copyright: (C) 2017 Choy KH. This is an open-access article distributed under the terms of the Creative Commons Attribution License, which permits unrestricted use, distribution, and reproduction in any medium, provided the original author and source are credited. 